\title{
The Burden of Romanticism: Toward the New Poetry
}

\author{
Roy Harvey Pearce
}

TO THE MEMORY OF ERICH KAHLER, 1885-1970

"Then look, I beg of you, try and

look within yourselves rather than

at me for what I shall discover."

-William Carlos Williams, "Writer's Prologue to a Play in Verse"

1

The burden of Romanticism is one which we all bear, however uneasily. If we can say anything about the modern ego, we can say that it is romantic-to recall the tautological title of a book which Jacques Barzun published some years ago. We would not have thought of troubling ourselves so much about the modern ego if Romanticism hadn't discovered it for us, taught us that the sense of ourselves we have when we face the fact that we are willy-nilly modern is precisely the burden it has placed upon us. Our egocentricism, even if we think of it as a too terribly refined version of Renaissance humanism, is at the heart of our power to have made the kind of world we have made-indeed, to have made ourselves in that world. Some day, we might have the kind of philosophical anthropology which will have absorbed the revelations of our philosophy, psychoanalysis, anthropology, sociology, theory of history, and the like-absorbed those revelations sufficiently to tell us what we are, where we have come from and how far we have got, where we turned off the strait road (if we did), and how we might once more get back on it (if we wish to, if we can, if there is still time)... . I propose here a much more modest exercise: to look at the developing situation of poetry since the later eighteenth century; to focus particularly on the achievement of "modern" American poetry-that is, the work of those masters who came into their own between the two world wars; and then to inquire into the situation of the "new" poetry, "post-modern" poetry. In order to make such a survey manageable I shall make the substantial center of my concern poetics: which I take to be the theory of how poems should-not always do-work, and also of the ground of authority for their working. In all, I shall be concerned to assess the burden Romanticism has in changing but genetically related ways put upon the poetry on which it has put its stamp. This will be then, within a quite limited purview, an essay in history-or triangulation.

It has been satisfactorily demonstrated, I think, that twentieth-century 
poetics has been a version, a stage in the development of, romanticist poeticsthis despite its so often tendentiously manifest anti-romanticism. For the sake of my argument, I must speak over-schematically, so to sharpen distinctions which are in actuality blurred but are nonetheless there. We can, then, ascribe to that development three stages:

1. The change, beginning more-or-less toward the end of the eighteenth century, from a "mimetic to a creative conception of poetry"-the mimetic conception being "no longer tenable when men ceased to share the cosmic designs that made mimesis meaningful." What was called for was the sort of poem which "would both formulate its own cosmic syntax and shape the autonomous poetic reality that the cosmic syntax permitted." (I quote and paraphrase some lines from Earl Wasserman's The Subtler Language.) Thus the poem as (in Mr. Wasserman's phrase) a "personal world-picture," a myth. Or (in Josephine Miles' phrase) as "the spirit's narrative . . . half-articulated and half-heard, but powerful in its force of implication."

2. The development of a "symbolist" poetics-with its assumption of the isolated poet who gained from his isolation an insight into the need to fuse his world-picture into an image in which the word was one with the thing, and so not amenable to analysis into discursive terms-the poet's isolation putting him safely out of the reach of those who would demand of language that it be commonsensical or "scientific." The symbolist's faith was that his "personal worldpicture" was ultimately grounded in a system of extra-human correspondences, insight into which his genius gave him.

3. The development of a modern, "post-symbolist" poetics, in which the symbolizing power of poetry is taken not only as carrying language beyond the purview of ordinary discourse, but as testing its authenticity as a means of getting beyond, or pointing to something beyond, that purview. When the guarantor of the correspondence of symbolic structures was taken to be the poet, then perforce the heart of poetry-the essence of poetry-was discovered to be language, words as he could make them into his medium and his only. The outcome of the development was this: that the highest test of language was taken to be its possible use in drawing a "personal world-picture," thus of comporting with the poet's archetypal sense of himself as being, before anything else, a person. Au fond, one's sense of oneself as a person, the argument went, derived from the certitude that one had no direct access to the things, or persons, of the world; one had only words. Since one wanted more, one had to want more, the question was: How might language be made to transcend language? Or: How might man break out of the confines of language and see what he must see?

To sum up my summing-up: The three stages may be described as having as their central concerns: 1. myth; 2. symbol; 3. language. In actuality, of course, the three concerns-with myth, symbol and language-have been from the beginning all integrally part of romanticist poetics. Moreover, they are steadily marked, as A. O. Lovejoy some time ago pointed out in his The Reason, the 
Understanding, and Time, by a wholesale delivery of the tasks (especially the epistemological tasks) of philosophy over to poetry-a process which began in immediately post-Kantian (i.e., "romantic") philosophy and culminated in the work of Bergson. So that T. E. Hulme's celebrated inauguration, in the name of Bergson, of an anti-romanticist poetics was a surrender camouflaged as a victory. Thus the whirlygigs of logic. My point is that in poetics, and accordingly in the practice of poetry, the focus of concern shifts, and at any one stage all three concerns tend to be subsumed under one, that at each of the later stages it is felt -and accordingly acted upon in the making of poems-that the preceding foci of concern have been accommodated to the present ones. We are now, I suspect, overpoweringly aware of the three concerns as comprising at once an evolutionary sequence and an increasingly integrated, perhaps self-identical, group, because we have come to the end of the line whose progress they mark and, confronted by the new poetry, wonder where we go, or will be taken, next.

We so much honor Freud as a central figure in "modernism," it occurs to me, because he tried to find a way of proving that actually the concern with myth was only a confused concern with symbol, the concern with symbol only a confused concern with language, and the concern with language in fact only an acceptance-at long last-of the "reality" of the core of our lives day-today (and night-to-night): consciousness and the price it demands of us and the rewards it offers. Human dignity, Freud discovered, was (or could be) a product of consciousness-such awareness of one's own history as would, at least in part, free man from being made by it, so that he could make it. With such knowledge we might put into language the record of our learning to live first with ourselves and then with one another. The record, in poetry, would be the act; the meaning, the being. It would be one of the tragic triumphs of consciousness, realizing its fullest-withal limited-capacities for expression and creation; and in doing so, literally, linguistically, discovering its own worth.

Freud's achievement surely has something to do with a curious factthat, for all the modern poet's announced concern for myth and symbol, he found it increasingly difficult to construct his articles of poetic faith out of them. As is shown by any close and chronologically systematic reading of his poems and his characteristic meditations on poetry, he tried myth and symbol, found them not quite enough and came to treat them as means, not ends (or ends-inbeginnings and beginnings-in-ends). This surely is a case where ontogeny recapitulates phylogeny. Herein, functioning as critic, he set the direction for all non-poets who would be critics too. This, I take it, was, and is, an aspect of his status as culture hero, of his (when he was at his best) heroic honesty. So that he drove himself to seek the grounds of myth and symbol-first by searching for their nature in the workings of the psyche, second by searching for their expressive forms. With the first, he studied "sensibility"; with the second, he studied "language." And inevitably the first was absorbed into the second, of which it is that special aspect which is of particular interest to poets and their exegetes.

Now, the movement in history from the first stage to the second and from the second to the third has been abundantly studied. I need only recall books by Meyer Abrams, W. J. Bate, Mark Schorer, Josephine Miles, Earl Wasserman, Edmund Wilson, Murray Krieger, Frank Kermode, Robert Langbaum, 
Joseph Chiari, and Richard Foster-not to mention a plentitude of essays-to indicate how widespread has been the discovery that from the later eighteenth century to our own time, the theory of poetry, whatever its makers may have said to the contrary, tends to be solidly romanticist. I wish here to attend to some aspects of the third, the twentieth-century, the modern, stage-then to inquire into its affiliations not only with what preceded but with what has followed it.

To do so, I must begin with some cautionary remarks. I must point out that, although we have established as fact the continuity of romanticist poetics into our own time, we cannot thereby read our twentieth-century "romantics" exactly as we read our nineteenth-century "romantics". I say this, because there has been some abortive effort at this self-defeating enterprise-curiously enough, by scholar-critics of Romanticism who somehow forget the prime definition of their field of interest: that it entails, as Professor Lovejoy long ago pointed out, an essential diversitarianism; which means that what is interesting and valuable in a poem, even if the poem be presumably grounded in some "universal," is interesting and valuable precisely as the poem is different from other poems-a concretely differentiated universal, so to speak.

The diversitarian hope, put at its most general, is expressed in these words of the sociologist George Simmel, in a discussion of the achievement of nineteenth-century thought:

I should like to think that the efforts of mankind will produce ever more numerous and varied forms wherein the human personality may affirm itself and demonstrate the value of its existence. In fortunate periods, these varied forms may order themselves into harmonious wholes. In doing so, their contradictions and conflicts will cease to be mere obstacles to mankind's efforts; they will also stimulate new demonstrations of the strength of these efforts and lead them to new creations.

Simmel's words (they come from his Fundamental Problems of Sociology, 1917) may now seem to us utopian; perhaps they seemed so to him. Romanticism did not in modernism come into its fortunate period. Which is to say that Western culture did not come into its fortunate period. The achievement of our great modernists was to affirm themselves and to demonstrate the value of their own existence-not to affirm their readers and to demonstrate the value of their existence: except potentially, as it were. This is an aspect of that overriding alienation which we take to have been (and to continue to be) the great malaise of modern man. Indeed, it was the modern poet's burden to express the symptoms, to teach his readers to discover them in themselves. His diversitarian hope was that as his readers discovered the symptoms, they would learn to survive them, and to be the better for it. For in the malaise, he knew, lay the ground of its own cure. Understanding it, his readers would know what it might mean not to be alienated-their relations to one another, as Emerson had said in "Experience," being casual and oblique. For the poet, the malaise was one of the sensibility; it was characterized by a failure in the sense of community-which made 
for a failure in the power to communicate. His language had not failed man. Rather, he had failed his language. He had failed to comprehend the power it gave him and also the responsibility possession of such power put upon him. He had failed to see in his use of language a prime means to the ever more numerous and varied forms wherein the human personality might affirm itself and demonstrate the value of its existence.

But perhaps he had not failed entirely. Perhaps he had only been timid, unwilling. Yet perhaps he had forestalled failure by recognizing its threat, its challenge. And in this forestalling the modern poets (romantic, romanticist, neo-romantic) were his leaders. The lesson which their practice-often enough as opposed to their preachment-taught is this:

Human creativeness in art prevents the recognized varieties of feeling, and established conceptions of the mind, from ever hardening into a final pattern. There are always surprises, the identification of new attitudes and states of mind through freely invented works of art that seem an exact expression of them for the first time. Any closed morality, so far left to itself, is always threatened with this unpredicted shock and disturbance, which suddenly illumines another possibility of human feeling and desire through the invention of a new form of expression. . . The idea of original art is the idea of an achievement that goes beyond any previous intention, and that must always be to some degree unexpected even by its maker. Even the most confident moralist must know that, sheltered within his own framework of thought, there are many potentially interesting features of behaviour and of feeling which he has not the means to notice. At some time they may be brought to the surface and, through the invention of forms of expression, recognised for the first time. If he reflects, he will acknowledge that these possible revelations must be infinitely many.

These are the words, not of a "neo-Kantian" like Simmel, but of a "Humean"the "Oxford philosopher," Stuart Hampshire in his Thought and Action (1959). I quote them not only because they serve to move my argument from a consideration of the diversitarian in general to the diversitarian in particular-in artbut because they may serve to indicate how the diversitarian faith still universally possesses us. For it characterizes the world which men have together struggled to make during the last two centuries. We quarrel-a Simmel would quarrel with a Hampshire, a Stevens quarreled with an Eliot, a Williams quarreled with them both-not about the diversitarian faith but in terms of it.

Thus it was in the nature of the modern poet's vocation, as that "antiromantic" Ezra Pound had it, that he must again and again "make it new." The notion that twentieth-century Romanticism is sufficiently comprehended by referring it back to nineteenth-century Romanticism-this notion derives from what I should call a "spurious" conception of romanticism, in order to set it against a more tenable conception, centering on the idea of the "diversitarian," which I should call "genuine." (I borrow the terms, from Edward Sapir's great 
essay "Culture: Genuine and Spurious.") Wallace Stevens, a "Romantic" in terms of both consciously held-to-doctrine and practice in poetry, put the matter thus in one of his posthumously published Adagia:

It should be said of poetry that it is essentially romantic as if one were recognizing the truth about poetry for the first time. Although the romantic is referred to, most often, in a pejorative sense, this sense attaches, or should attach, not to the romantic in general but to some phase of the romantic that has become stale. Just as there is always a romantic that is potent, so there is always a romantic that is impotent.

Genuine Romanticism and spurious; fresh Romanticism and stale; potent Romanticism and impotent. To discriminate between the one and the other: this perhaps is the historian's real problem. One of the ironies of the history of modernist poetry surely is that poets like Pound and Eliot, the Southern Fugitives, and many of their epigones in the 1940's and 50's-all preached against an impotent Romanticism, a stale Romanticism, a spurious Romanticism, on behalf of one potent, fresh, and genuine; and claimed thereby to be anti-romantics, even "classicists." The irony, however, is only superficial, and is contained by the fact that the history of literary Romanticism, and other kinds too, is the history of the discovery of the potency of the diverse-if I may make so bold as to combine the language of a Stevens and a Lovejoy. Or: to think of that history in terms of the making of poems-it is the history of a seeking of a means, an authoritative medium, whereby to evoke the potency of the diverse. Modernism-the third stage in the development of Romanticist poetics-centered not on myth or symbol but on language. I think if we get clear the burden of understanding put upon us by the modernist obsession with language, we shall be in a position to comprehend-at least tentatively-the burden of understanding put upon us by the new poetry, and to begin to elucidate its particular obsession, thus its poetics.

I quote from three well-known statements about poetry by modern poets. From T. S. Eliot's "The Social Function of Poetry":

We may say that the duty of a poet, is only indirectly to his people; his direct duty is to his language, first to preserve, and second to extend and improve. In expressing what other people feel he is also changing the feeling by making it more conscious; he is making people more aware of what they feel already, and therefore teaching them something about themselves.

From Wallace Stevens' “The Noble Rider and the Sound of Words":

The deepening need for words to express our thoughts and feelings which, we are sure, are all the truth that we shall ever experience, having no illusions, makes us listen to words when we hear them, loving them and feeling them, makes us search the sound of them, 
for a finality, a perfection, an unalterable vibration, which it is only within the power of the acutest poet to give them. Those of us who may have been thinking of the path of poetry, those who understand that words are thoughts and not only our own thoughts but the thoughts of men and women ignorant of what it is that they are thinking, must be conscious of this: that, above everything else, poetry is words....

\section{From William Carlos Williams' Introduction to The Wedge:}

A poem is a small (or large) machine made out of words. ... When a man makes a poem, makes it, mind you, he takes words as he finds them interrelated about him and composes them-without distortion which would mark their exact significances-into an intense expression of his perceptions and ardors that they may constitute a revelation in the speech that he uses ... There is no poetry of distinction without formal invention, for it is in the intimate form that works of art achieve their exact meaning, in which they most resemble the machine, to give language its highest dignity, its illumination in the environment to which it is native.

Now, it is a mere truism to say that poets have always been concerned with words, with language. But this concern has been-or was, say, before the latter part of the eighteenth century-a concern subsidiary to a larger concern: at one extreme, to celebrate in all its rich humanity, and at the other, to denigrate in all its vacuous inhumanity, the ways of men and their gods. (To denigrate is to celebrate inversely, out of a sense of what could or should have been.) The history of literary Romanticism is the history of the gradual metamorphosis of the major concern into the subsidiary, as increasingly that which was to be celebrated-the ways of men and their gods-became not an assured reality, locatable in time and space, anchored in a question-transcending faith, but first a matter of myth, then a matter of symbol, then a matter of language. Those whom this development made unhappy would have said something like "mere" myth, or symbol, or language. Poets have striven to prove that it is not a question of "mere" myth, or symbol, or language; that in man's increasing discovery of the potentiality of his humanity as humanity, understanding the power of myth, or symbol, or language is a sufficient and necessary condition for whatever celebration in art the nature of man allows.

I would characterize the great achievement of modernist poetry, that of the dominating sensibility through World War II, thus: The poet would still celebrate the ways of men and their gods; the testimony of the poems of those writers I have cited is sufficient proof of this. But first he had to celebrate (or denigrate, I repeat), and so enlarge the potential for, man and the ways of man with language, and likewise language and the ways of language with men. Where once the poet could say "proper words in proper places," now he had to say "What words in what places?" Or: "We have words, but no places to put them in; we must make places to put them in." The poet could not simply assume his 
essential humanity; now he was bound to prove it; prove it linguistically; prove that men were men precisely as they at once used language and were used by it. The traditional function of poetry had been, through its linguistic transformations, to enhance, deepen, and enlarge man's vision of his world and himself in it. Now that function was to make such a vision possible. The vision was not to be attained until after, through his creation of a poetic experience, the poet could not only make us grant the possibility of the vision but also invent for us the ways of realizing it. Words communicate, the implicit argument went, because they are not only the poet's but the reader's; yet only the poet can tell us what they really mean, how their meaning may be released so that we will all know what they really mean. The great make-believe of most modern poetry was that the reader was composing the poem along with the poet. But then: It turned out not to be entirely make-believe. For the reader turned out to have been learning that it was possible, in spite of all the forces which tended to disintegrate and to reduce the languages which might hold modern communities together, not only to find words but the proper places for them, to use language as a means of realizing oneself as a man-a man perhaps capable even of having gods. (Let me propose schematically that in the history of romanticist poetics through modernism we get this evolving set of oppositions against the forces which disintegrate and reduce man's capacity to make poems: against mechanistic rationalism, the poetics of myth; against positivistic scientism, the poetics of the symbol; against behaviorism and mass communications, the poetics of language.)

Thus it would seem that the characteristic modern poem had as its intention not only registering its substantial concerns but attaining the state, through its working, of an ars poetica. (I would here cite as evidence not only of the substance but the mode of Four Quartets, the Cantos, Paterson, The Bridge, and Notes toward a Supreme Fiction, to name only the principal masterworks in this vein.) The poetics of Romanticism had in the twentieth century come to be a poetics wherein, to quote some words of I. A. Richards (from his Speculative Instruments), poetry might well be defined as "words so used that their meanings are free to dispose themselves; to make up together whatever they can." Needless to say, perhaps, only a poet could thus free words; and freeing them, he put to a specifically linguistic test whatever doctrines they might project, perhaps transformed those doctrines in the testing and projecting.

Here we come up against the crucial problem in the modernist version of the romantic theory of poetry. What does it mean to impute agency to words -to say that, freed, as they can be only in poems, they can act freely? Surely this theory of poetry entails a richer and more inclusive linguistics than any we have even now; and surely Richards' statement (which he inevitably made the substance of poems) is one which relates the practice of modernist poetry to the contemporaneous practice of philosophy, theology, anthropology, psychology, and the rest-all concerned to understand the meaning of meaning, to preserve against all onslaughts the capacity of language to be meaningful. Here the concerns of modernist poetry lay the groundwork for the concerns of "post-modern" poetry. How-to recall Eliot's words-does a poet "extend and improve" language? Why -to recall Stevens' words-is it that the poet can best satisfy our "deepening need for words?" How-to recall Williams' words-can a poet "compose" words "as he 
finds them interrelated about him" and yet not "distort" them? What is the concept of the meaning of meaning entailed here? What, in short, is the relation between the poetic use of language and the health of the sensibility, between the poetic use of language and the situation of modern and post-modern manwherein consciousness of self has become self-consciousness? On what grounds in linguistic theory, not to say ontology and metaphysics, may we place our faith in poetry? Such are some of the issues still raised by modern poetics and the poetry out of which it issues.

Poets, on this argument, had become the unacknowledged grammarians of mankind, all the while hoping to be more; but knowing all the while that if they were not this, they were nothing. Romanticism, then, as it issued into twentieth-century poetry, had not necessarily relieved man of the burden of orthodoxy, original sin, history-as has so often been claimed. Nor had it necessarily supplied man with a religion of art to take their place. For these are matters of doctrine; and I am persuaded that one of the lessons to be learned from the history of Romanticism is that its central tenet-the potency of the diverse-transcends doctrines, is a means, an absolute, of testing and judging doctrines, which are relative. So that matters of doctrine comprise a necessary but not a sufficient condition in the practice of most of our great modern poets and may be assented to or denied accordingly-the assent or the denial having no necessary relationship to our estimate of the achievement and value of the poets. The sufficient condition of the practice of poetry is a concern with the viability in language of matters of doctrine as they do and do not manifest the potency of the diverse. Modern poetics, a romanticist poetics, thus considered, meant not to teach man what to believe. Rather, it wanted to teach him how to believe, the necessary conditions of belief. It instructed him that he could comprehend, and so properly assume, the burden of any doctrine only if he could conceive of it as uniquely, humanly, his own; only if it did not violate his sense of the potency of the diverse; only if he could find the right words for it; only if it would be amenable to poetic expression, so as to be claimable as his own. We don't have to believe a poem, he could say; we have only to believe in it.

No modern poet of worth, not even an ostentive romantic-wanted to have his religion split-to recall some cruelly influential, but mistaken, words from T. E. Hulme's "classic" summa contra Romanticism. The modern masters wanted just to be sure that it was really theirs; that they could put it into words which comported with their sense of themselves as persons first and wanderers lonely as a crowd second; that, whatever else it might require of them, it would answer to their sense of the potency of the diverse. For they declared that in the potency of the diverse, for them above all latent in the use of language, lay their hope for the dignity not only of man, but of men: their romantic humanism. This is what they surely have taught the poets who have come after them, the newest poets. For out of the poetics of language, out of the poetics of myth and symbol, there has risen, there is rising, a new, or renewed, poetics-one of statement and, more important, of dialogue. (Which is to say, too long after the fact, that modern, post-symbolist poetics was, for well and for ill, a poetics of monologue). 
Are our recent poets (acting, I must emphasize, on our behalf; acting out our struggles to educate ourselves) learning the lesson of their modern masters? I think so-although at this stage I am not altogether clear, because they are not, as to exactly what the lesson is and what, once learned, it will involve. (One never really knows what the lesson is until he has learned it; and then it is part of the sort of history I am sketching now.) We can, as always when dealing with the contemporaneous, mark out "tendencies." I think that it is reasonably clear that in this "post-modern" era we are being moved into a new stage in the history of romanticist poetics, therefore a new stage in the history of ourselves. In the newer poetry-so it seems to me-the sense of an authentic language, authentically used, is somehow strong enough to let poets conceive of themselves as living out their imagined lives in a world whose "public" aspect, however threatening, is not such as to threaten the very existence of poetry itself. It is as though poetry had come through its post-Renaissance phase sufficiently strengthened in ego power to be now capable of putting myth, symbol, and even language where they properly belong-in human space and history, not outside of it; as though poetry were once more capable of being poetry, mere poetry; as though it were once more ready to stake out its own claim as being a central means whereby man makes not himself but his knowledge of himself; as though "man" as subject were being rediscovered in "reality" as object and vice-versa-so that the subject-object distinction at the heart of romanticist poetics were being dissolved. Accepting the sheer factuality, the sheer giveness, of the human condition, recent poets seem to me to have on the whole ceased trying to explain the world and started to try to know it; and they strive to master, as against being mastered by, implicit principles of explanation (myths, symbols, even their own kind of linguistics). That is, they try to "use" (because they will not be "used by") myth and symbol, and try also to develop the kind of language which, as language should, points beyond itself, even takes the poet beyond himself: from his sense of man-as the power of language, being a power of consciousness, may transform it-into a sense of men.

A poet like W. D. Snodgrass may remind us at times of Auden, at times of Stevens, at times of many others of his immediate modernist forebears; but he seems to be trying to develop the means whereby he may make statements not about making statements but about objects or events whose import is worth discovering and so stating, not about the experience of poetry and its ground but about an experience through poetry and its "significance":

These trees stand very tall under the heavens.

While they stand, if I walk, all stars traverse

This steep celestial gulf their branches chart.

Though lovers stand at sixes and at sevens

While civilizations come down with the curse,

Snodgrass is walking through the universe.

I can't make any world go around your house.

But note this moon. Recall how the night nurse 
Goes ward-rounds, by the mild, reflective art Of focusing her flashlight on her blouse.

Your name's safe conduct into love or verse;

Snodgrass is walking through the universe.

Your name's absurd, miraculous as sperm And as decisive. If you can't coerce One thing outside yourself, why you're the poet!

What irrefrangible atoms whirl, affirm

Their destiny and form Lucinda's skirts!

She can't make up your mind. Soon as you know it,

Your firmament grows touchable and firm.

If all this world runs battlefield or worse,

Come, let us wipe our glasses on our shirts:

Snodgrass is walking through the universe.

(“These Trees Stand ...")

This just may border on the trivial; the poet may just be using his capacity as poet to defend himself and his readers against the situation of which he treats. Snodgrass and his kind may turn out to have been the Longfellows of our age, as, at the other extreme a poet like Gregory Corso and his kind, trying to make new the language of all the "mad" poets from Smart and Blake to Rimbaud and Artuad may turn out to have been the Lindsays:

On the steps of the brightmadhouse

I hear the bearded knell shaking down the woodlawn

the final knell of my world

I climb and enter a fiery gathering of knights

they unaware of my presence lay forth sheepskin plans

and with mailcoated fingers trace my arrival

back back when on the black steps of Nero lyre Rome I stood

in my arms the wailing philosopher

the final call of mad history

Now my presence is known

my arrival marked by illuminated stains

The great windows of Paradise open

Down to radiant dust falls the curtains of Past Time

in flocks of multicolored birds

Light winged light $\mathrm{O}$ the wonder of light

Time takes me by the hand

born March 261930 I am led $100 \mathrm{mph}$ o'er the vast market of choice

what to choose? What to choose?

Oh-and I leave my orange room of myth

no chance to lock away my toys of Zeus

I choose the room of Bleecker Street 
A baby mother stuffs my mouth with a pale Milanese breast

I suck I struggle I cry O Olympian mother

unfamiliar this breast to me

Snows

Decade of icy asphalt doomed horses

Weak dreams Dark corridors of P.S. 42 Roofs Ratthroated pigeons

Led $100 \mathrm{mph}$ over those all too real Mafia streets

profanely I shed my Hermean wings

O time be merciful

throw me beneath your humanity of cars

feed me to giant grey skyscrapers

exhaust my heart to your bridges

I discard my lyre of Orphic futility

And for such betrayal I climb these bright mad steps

and enter this room of paradisaical light

emphemeral

Time

a long long dog having chased its orbited tail

comes to grab my hand

and leads me into conditional life

("In the Fleeting Hand of Time")

The poems I have quoted run the risks of their makers' romantic humanism. So does this one by James Wright-which, since it must be political, refuses to be obliquely or ironically so:

In the Shreve High football stadium,

I think of polacks nursing long beers in Tiltonsville, And gray faces of Negroes in the blast furnace at Benwood,

And the ruptured night-watchman of Wheeling Steel,

Dreaming of heroes.

All the proud fathers are ashamed to go home.

Their women cluck like starved pullets,

Dying for love.

Therefore,

Their sons grow suicidally beautiful

At the beginning of October,

And gallop terribly against each other's bodies.

("Autumn Begins in Martin's Ferry, Ohio")

And so does this one, by Gary Snyder-which, since it will confront the natural world, will strive to penetrate and be penetrated by it: 
Pressure of sun on the rockslide

Whirled me in dizzy hop-and-step descent, Pools of pebbles buzzed in a Juniper shadow, Tiny tongues of a this-year rattlesnake flicked, I leaped, laughing for little boulder-colour coil-

Pounded by heat raced down the slabs to the creek

Deep tumbling under arching walls and stuck

Whole head and shoulders in the water:

Stretched full on cobble-ears roaring

Eyes open aching from the cold and faced a trout.

("Water")

What strikes me about these poems in contrast to those of their modernist forebears is how carefully they trace out the contours of the experience they would tell us of, so carefully as to make it possibly ours. Even if they would choose to make out Williams (and also Pound as he resembles Williams) as their particular master, even if they take themselves to be realizing Williams' concern to create a poem of projective sympathy, they go beyond Williams. Their forebears-Williams among them-characteristically fractured or shattered their experiences and then reconstellated them according to principles dictated by a concern to discover if language could admit them into the sensibility. The poems I have quoted-two by men deliberately putting themselves on a leash, two by men as deliberately running wild-"do" whereas those of their forebears "are." The deliberateness is all, perhaps when it should be just enough.

The deliberateness is a product of a deeply felt dialogic relationship with the reader. The mode of control, poem-to-poem, varies enormously, but the end is pretty much the same: to share with, not to talk to, the reader.

John Ashberry makes flat factuality generate a surreal world, almost a world of fantasy but not quite. He will make the familiar unfamiliar, so in the process to know it for what it really, humanly, is:

I write, trying to economize

These lines, tingling. The very earth's

A pension. My life story

I am toying with the idea.

I'm perfectly capable (signature)

The kerosene white branches the stadium

There is no reason to be cold

Underneath, it is calm today.

For the moment, clement day

Observes our transactions with kindly eye.

There is no reason to suppose

Anything of the kind will occur.

I oppose with all the forces of my will

Your declaration. You are right

To do so. The street catches auburn 
Reflections, the start is here.

You may have been well.

You limit me to what I say.

The sense of words is

With a backward motion, pinning me

To the daylight mode of my declaration.

But ah, night may not tell

The source! I feel well

Under the dinner table. He is playing a game

With me, about credits.

I have to check in the hall

About something.

The invitation arrived

On the appointed day.

By nightfall he and I were between.

The street rages with toil.

Can you let yourself, a moment, put down your work?

(from "Measles")

Richard Brautigan will push the delights of complicit simple-mindedness all the way:

I sit here dreaming

long thoughts of California

at the end of a November day

below a cloudy twilight

near the Pacific

listening to The Mamas and The Papas

THEY'RE GREAT

singing a song about breaking

somebody's heart and digging it!

I think I'll get up

and dance around the room.

Here I go!

(“Our Beautiful West Coast Thing”)

David Ignatow will annotate with maximum precision a brief encounter and in the same breath (the poem moves that way) make explicit its implications. The poet's business is no longer a matter of what Eliot called hints and guesses:

Say pardon to a bum, brushing past him.

He could lean back 
and spit

and you would have to wipe it off.

How would you explain

that you have insulted

this man's identity,

of his own choosing;

and others could only scratch

their heads and advise you

to move on

and be quiet.

Say pardon

and follow your own will

in the open spaces ahead.

("Say Pardon")

And Robert Duncan wills himself to be prophetic; the will powers his poem to its openly cosmic end. Still, the poet faces up to the fact of his limitations, which are his reader's:

Grand Mother of Images, matrix

genetrix, quickening in rays

from the first days of the cosmos,

turning my poet's mind in tides of

solitude, seductive reveries, fears, resolves, outrage

yet

having this certain specific agent I am,

the shadow of a tree wavering and yet staying

deep in it,

the certain number of days rendered uncertain,

gathering,

animal and mammal, drawing such milk

from the mother of stars.

(from "In the Place of A Passage 22")

I have instanced here the work of eight of the "new" poets. Although it avoids classification by schools, peer-groups, manifestos, influences, and the like, the selection is not quite at random. These are, simply enough, some of the new poets whose work I find-in differing degrees, to be sure-compelling. "Compelling" may be too strong a word. I mean just that these are some of the new poets whose work I find myself altogether willing to make part of my own proprioception. 
"Proprioception"-the word comes out of psychology-is a central concept in the new poetry, at least for what two poets have made it out to mean. Speaking of his work and that of his peers, Snodgrass said in May 1962 (his words are reported in a 1963 pamphlet, Approaches to the Study of TwentiethCentury Literature):

We are like the Greeks in this: being great explorers of physical space, they were obsessed with the problem of "limit." How far can you go, they asked, practically and morally?

The problem of limit, too, encompasses certain psychological problems, especially that of proprioception: the recognition of the self as an object positioned in space relative to other objects positioned in space; or, the self as a subject positioned in space relative to other subjects. But this space must be seen as endless; we must see ourselves as finite dancers on a stage, not infinite, but undefined. This absence of definition gives us a chance to move fully into that relativism proposed so long ago by men like Giordano Bruno, but which so few have dared to explore ....

In a coincidence happy for the historian, Charles Olson, a poet who is centrally concerned with "the problem of 'limit," "was writing, also in May 1962, a vatic manifesto (published in 1965) called Proprioception:

The advantage is to "place" the thing, instead of it wallowing around sort of outside, in the universe, like, when the experience of it is interoceptive: it is inside us/ \& at the same time does not feel literally identical with our own physical or mortal self (the part that can die). In this sense likewise the heart, etc, the small intestine etc, are or can be felt as-and literally they can be-transferred. Or substituted for. Etc. The organs.-Probably also why the old psychology was chiefly visceral: neither dream, nor the unconscious, was then known as such. Or allowably inside, like.

". . . limits/are what any of us/ are inside of." Olson writes in the fifth of his Maximus Poems. But inside those limits of human space and time, there are available the means of achieving definition through relationship and dialogue, subject to subject. I do not mean here to avoid the issue of the degree to which in their work two poets like Snodgrass and Olson differ. I mean only to indicate how-in their concern to define relationship and dialogue as those of subject to subject, not subject to object-they conceive alike of the vocation of the new poet.

And (since in matters of this importance, one must be quite blunt) I would not deny the dangers of the new poets' way. For striving toward the subject-to-subject relationship, validating the proprioceptive mode, can be an act so strained and desperate as to lead first to the homogenization and then to the 
annihilation of the sensibility. Expanding the definition of "man," exploring the definition to the utmost-this can lead to an act of suicide mistakenly made out to be a rite of passage. Love of the other may become a totally sentimental, bathetic, confused indulgence of self, and there might be generated a sense of the world in which polymorphism reigns over all. Thus Michael McClure:

\section{OH BRIGHT OH BLACK SINGBEAST LOVEBEAST CATKIN SLEEK}

spined and gullet shaped. Free me

in the tree-lighted evening and full cool

morning. $\mathrm{OH}$

VISION free me erect and huge to VISION

DEEP-DELVED

OUTDELVING. BANNER-

hung and warm warmly gestured

star gestured in

the coldness.

Fingers spread pointing.

The only vision sight-sense.

The appropriate gloss can only be these opening lines from McClure's "Reflections after a Poem" (the poem being his translation of Nerval's "Black Spot”) :

LET US THROW OUT THE WORD MAN! Such poems as this translation of Nerval remind me that I am a MAMMAL! We have almost worn out the word man. This is the young creature looking into the world. The poem makes me see the surge of life. The word MAN is not romantic enough! ...

Thus one extreme example-one phase of the new poetry as it projects itself out of the proprioceptive orbit into absurdity. (The old romanticist rule still holds: Everything ventured, nothing gained.) But even as we are aware of this danger, this risk, unwisely and unintelligently (that is the key word!) courted, we must remember that it will in the long run be the orbit that matters. It is that orbit which I have been trying to trace in this essay-that orbit, and 
as I have said, the sense of the new poet's vocation which it defines, the poetics which it articulates. Within this poetics are the facts of our case as the new poetry lets us confront them.

Moreover, if we were to look at the later work of poets a generation or so older, poets "transitional" between the "modern" and the "new"Berryman, Shapiro, Lowell, Warren, Schwartz, Roethke, for example-we would find analogous "proprioceptive" qualities and conditions: a turning to narrative forms, explicit or implicit; an attending to states of consciousness as they are implicated in action; an increasing sense of inter- (as opposed to intra-) personal relations; an exploding diversity, a sometimes awkward honesty, a directness, an openness; a search for the face behind the persona. We would perhaps be surer of this poetry than of that I have quoted. But the aim of this essay is to suggest how, even as we reconsider briefly that of which we may be fairly sure, we may try out unsureness. Secure in the history our poets have made, we may well risk being insecure in the history they are making. Nonetheless, the qualities and conditions I have noted are there, in older poets and younger. And the reader is no longer a hypocrite, peeping over the poet's shoulder, hoping against hope not to have to acknowledge that he is the poet's double, his brother-but one whom the poet would encounter, with whom he would initiate a dialogue. Language becomes a medium for as well as a medium in. Myth and symbol are parts of the poet's vocabulary, not its formal, much less final, cause.

It is, then, as part of their essential heritage from Romanticism that poets of the generation of Eliot, Stevens, and Williams, our great "Moderns," took upon themselves the obligation to preserve, refine, and extend our language. Their destiny was to teach poets of following generations to use it in such a way that they, or their progeny, might one day be audible witnesses to that great romantic vision: the transformation of the humanism of the one into the humanism of the many. And just at the point in history when the material conditions of life may, at their level, make this transformation possible, such conditions bring to bear a power for dehumanization which might as well make it impossible on other, higher levels. It will be possible, of course, only if a power for humanization is brought to bear. And the poet is ready, as in the nature of his relation to his society he is always ready. He has his language, which incorporates his understanding of symbol and myth and the ideas of order projected thereby. But he wants to discover and project his own idea of order, to walk through his own and his fellows' universe and to know the conditional life. For him symbol and myth can be no more than heuristic, although it is quite true that the evidence of his work shows often that his poems know this better than he does. He senses that at some point he must shed his Hermean wings and discard his lyre of Orphic futility. He will make his firmament grow touchable and firm. $\mathrm{He}$ will declare quite flatly "therefore." He will make his dizzy hop-and-step descent. $\mathrm{He}$ will take the whole earth to be his pension. He will get up and dance around the room. He will say Pardon, so that he may follow his own will. He will seek his and his fellows' Grand Mother of Images. Language, he has been given to discover, is to talk with. And if talking about oneself is inevitable, still it is important not to talk only to oneself. Too, it is important to listen. 
For the poet knows what his magus knows: “. . . that an individual life is the accidental coincidence of but one life cycle with but one segment of history; and that for him all human integrity stands and falls with one style of integrity of which he partakes." The magus I quote is Erik Erikson-one psychoanalyst who, in practice and theory, shows that he understands the sort of goal which, for all their strained deliberateness (a kind of reaction-formation?) the poems I have quoted point toward. This shouldn't surprise us, however. For psychoanalysis is the modern ego's best account of itself. And just as recent poetry has striven to initiate its true dialogue with the world, so has recent psychoanalysis.

I have a sense that the poet would now use his language so as to humanize-perhaps to make symbol and myth human, perhaps to discover that they are after all human and are therefore our means, in poetry and out, of discovering and so accepting and enlarging our humanity. The poet is still the kind of utopian we need, the utopian of the present. He is the last romantic, as has been virtually every poet since the later eighteenth century at least. For he knows that it is in the nature of every phase of Romanticism that it be the "last," if its artists are continually to actualize the potency of the diverse. In art, the last shall always go first.

Theodore Roethke, an older and probably a wiser poet than the ones I have so far quoted, called one of his books Praise to the End! The phrase, of course, is Wordsworth's; the passage is from The Prelude (I, 346-350). Taken out of its essentially symbolic, mythic context, so that it renders just Wordsworth's all too human sense of himself, it marks the tone and substance, the characteristic import, not only of Roethke's poetry but that of many of his younger contemporaries, whose future was in his bones:

\section{... How strange, that all}

The terrors, pains, and early miseries,

Regrets, vexations, lassitudes interfused

Within my mind, should e'er have borne a part,

And that a needful part, in making up

The calm existence that is mind when I

Am worthy of myself! Praise to the end!

I have said that the passage is here quoted out of context. And I have shifted the context even more by speaking not of Roethke and his generation, but of the generation of Snodgrass, Corso, Wright, Snyder, Ashberry, Brautigan, Ignatow, Duncan, and (alas) McClure. But then, this is what Romanticism has done -steadily shifted modern man's context, until at last he can hope to be capable at once of finding a proper context and making it his own, of accepting no context unless he can in poems and all his creative endeavors know it as his own. It is of the essence of the latest phase of Romanticism that he should have discovered that his context is not his own unless it is his fellows', and not theirs unless it is his. Perhaps it will turn out to be God's-but surely not unless it is at least man's. At 
least. And the terrors, pains, miseries, regrets, vexations, lassitudes are not only within man's mind but without. The boon of a calm existence must be not only his but his community's. We have been true enough to the burden Romanticism has put upon us to have invented-that is, at once discovered and created-a poetics of dialogue. The poet speaks, so to be spoken to, so to speak again . . . Praise to the end! 